\title{
Composite resin for restoration of a posterior tooth and polishing: clinical case report
}

Resina composta para restauração de um dente posterior e polimento: relato de caso clínico Resina compuesta para restauración y pulido de diente posterior: reporte de caso Frederico dos Reis GOYATÁ ${ }^{1}$

Sávio Morato de Lacerda GONTIJO²

José Alcides Almeida de ARRUDA ${ }^{2}$

João Batista NOVAES JÚNIOR ${ }^{2}$

Ivan Doche BARREIROS ${ }^{2}$

Célia Regina Moreira LANZA ${ }^{2}$

Amália MORENO²

${ }^{I}$ Department of Dentistry, School of Dentistry, Federal University of Alfenas (UNIFAL), 37.130-000, Alfenas, MG, Brazil

${ }^{2}$ Department of Oral Surgery, Pathology and Clinical Dentistry, School of Dentistry Federal University of Minas Gerais (UFMG), 31.270-901, Belo Horizonte, MG, Brazil

\begin{abstract}
The aim of the present report was to describe a case of direct composite resin restoration in tooth 46, with emphasis on the importance of polishing. A 21-year-old female patient dissatisfied with the aesthetic amalgam restoration of her tooth 46 came to the our institution for correction of the situation. The procedure performed consisted of registration of occlusal contacts, selection of resin color, removal of amalgam restoration, coronal reconstruction with composite resin, occlusal adjustment, finishing and polishing, with the use of atomic force microscopy of the resin before and after polishing. A correct clinical protocol for the posterior composite resins is fundamental for the optimization of aesthetic results, for clinical performance and for consequent restorative longevity. The atomic force microscopy images of the resin used before and after polishing emphasize the necessity and clinical importance of this operative step.
\end{abstract}

Descriptors: Dental Materials; Dental Restoration, Permanent; Dental Polishing; Microscopy.

\section{Resumo}

O objetivo do presente relato foi descrever um caso de restauração direta de resina composta no dente 46, com ênfase na importância do polimento. Paciente do sexo feminino, 21 anos, insatisfeita com a restauração estética de amálgama no seu dente 46, procurou nossa instituição para correção da situação. O procedimento realizado consistiu no registro dos contatos oclusais, seleção da cor da resina, remoção da restauração de amálgama, reconstrução coronária com resina composta, ajuste oclusal, acabamento e polimento, com o uso da microscopia de força atômica da resina antes e após o polimento. O protocolo clínico correto para as resinas compostas posteriores é fundamental para otimização dos resultados estéticos, para o desempenho clínico e consequente longevidade restauradora. As imagens de microscopia de força atômica da resina utilizada antes e após o polimento enfatizam a necessidade e a importância clínica desse procedimento.

Descritores: Materiais Dentários; Restauração Dentária Permanente; Polimento Dentário; Microscopia.

\section{Resumen}

El objetivo del presente trabajo fué describir un caso de restauración directa con resina compuesta en el diente 46, destacando la importancia del pulido. Paciente de sexo femenino, 21 años, insatisfecha con la restauración de amalgama en el diente 46, buscó atención en nuestra institución. El procedimiento realizado consistió en registrar los contactos oclusales, selección del color de la resina, remoción de la restauración de amalgama, reconstrucción de la corona con resina compuesta, ajuste oclusal, acabado y pulido con el uso de microscópio de fuerza atómica en la resina antes y después del pulido. Un protocolo clínico correcto para el uso de resinas compuestas posteriores es fundamental para optimizar los resultados estéticos, para el desempeño clínico y consecuente longevidade de la restauración. Las imágenes del microscópio de fuerza atómica de la resina utilizada antes y después del pulido muestran la necesidad y la importancia clínica de usar ese procedimiento.

Descriptores: Materiales dentales; Restauración Dental Permanente; Pulido Dental; Microscopía.

\section{INTRODUCTION}

Currently, the media and society are increasingly valuing aesthetics and the quest for external perfection has reached great intensity in dental offices. To meet patient demand, restorative dentistry has evolved a lot in terms of materials and restorative techniques ${ }^{1}$. The amalgam, until the late 1990s, was the only option for restorations in posterior teeth. With the evolution of adhesive systems and composites, together with the ability of clinicians to mimic the color, shape and texture of natural teeth, the use of composite resins has become widespread, with great efficiency and clinical success ${ }^{2}$.

The clinical indication of composite resin in posterior teeth can be attributed to the advantages of these materials when compared to amalgam, such as greater preservation of healthy dental tissue, possibility of repair during maintenance appointments, and excellent aesthetic result ${ }^{3-6}$. The composite resins are well indicated when there are occlusal and occlusal-proximal boxes that are not extensive, without loss of cusps and with cervical endings in enamel ${ }^{5,7}$.

Modern resins have a higher percentage of charge volume and a smaller particle size, which substantially improve the mechanical resistance to masticatory forces and surface smoothness ${ }^{8,9}$. When a direct restoration is performed with composite resin, it is necessary to finish and polish in order to obtain greater surface smoothness, avoiding plaque accumulation and providing periodontal tissue health, in addition to increasing the longevity of the restorations ${ }^{10,11}$. Microscopic analysis by atomic force microscopy permits qualitative evaluation of the effects of finishing and polishing on the surfaces of composite resins ${ }^{12}$. The objective of the present study was to report a clinical case based on the confection of a composite resin restoration in tooth 46 and to emphasize the importance of finishing and polishing after the restoration, as illustrated in atomic force microscopy images. 


\section{CLÍNICAL CASE}

A 21-year-old female patient came to the Department of Restorative Dentistry (Universidade Federal de Minas Gerais, Belo Horizonte, MG, Brazil), dissatisfied with the aesthetics of an amalgam restoration in tooth 46 . The initial procedure was prophylaxis with a Robinson brush (Microdont, Brazil), pumice stone (SS White, US) and water. Then, the colors of the composite resin, colors A1 and A2 (Venus, Heraeus, Germany) were selected. As the amalgam restorations were well adjusted, the contact points were determined previously with the aid of carbon film strips (Figure 1A). After absolute isolation (Madeitex, Brazil), the amalgam restoration was removed with a 1046 diamond tip (KG Sorensen, Brazil) with care taken to avoid wear of the dental structure by only touching the amalgam restoration (Figure 1B). After completion of the cavity preparation, conditioning was performed with $37 \%$ phosphoric acid (FGM, Brazil) for 30 seconds on the enamel and 15 seconds on the dentin (Figure 1C).

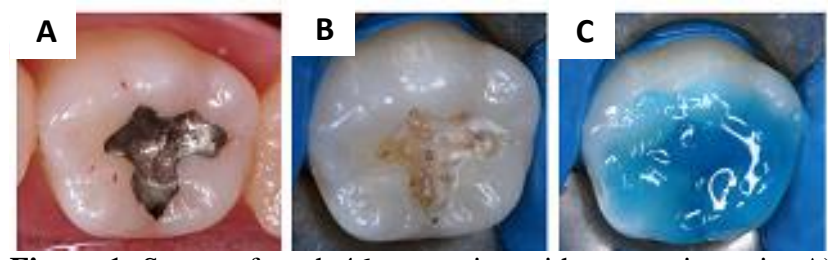

Figure 1: Stages of tooth 46 restoration with composite resin; A) registration of occlusal contacts; B) cavity preparation after removal of the amalgam restoration; C) cavity conditioning with $37 \%$ phosphoric acid.

The cavity was washed with copious water and dried with absorbent paper. The Gluma 2 Bond adhesive system (Heraeus, Germany) was applied, followed by photoactivation for 20 seconds (LED light curing light Flash Power - Discus Dental, US) with $1100 \mathrm{~mW} / \mathrm{cm}^{2}$ (Figure $2 \mathrm{~A}$ ).

The tooth was reconstructed by the incremental technique with composite resins, colors OA2 and A2 (Charisma Classic, Heraeus, Germany). The composite was inserted with the aid of a \#1 spatula, followed by photoactivation of each increment for 20 seconds. The first increment was started through the pulp wall and buccal and lingual cusps (Figure 2B and Figure 2C) ${ }^{7}$.
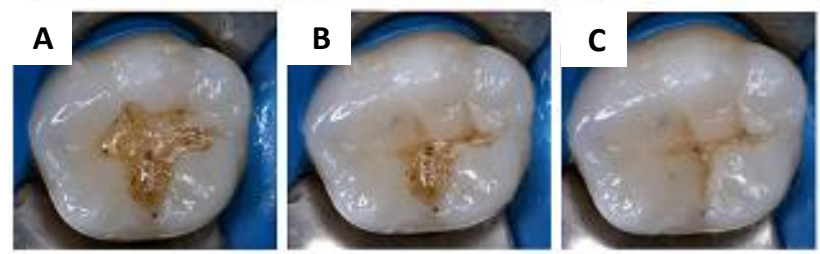

Figure 2: A) application of the adhesive system and photoactivation for 20 seconds; incremental insertion of the composite resin by reconstructing the B) buccal and C) lingual cups.

Occlusal adjustment was performed with 2135 diamond tips (KG Sorensen, Brazil) by checking the contact points previously determined with carbon strips (Accu Film II, Parkel, USA). The finishing and polishing of the restoration were finalized seven days after the preparation using a silicon carbide brush, abrasive rubbers and polishing paste (Jiffy brush system and Jiffy points, Ultradent, USA) (Figure 3A and Figure 3B ). At present, the patient has been followed up for 1 year without the presence of marginal infiltration or any change indicating caries lesion.
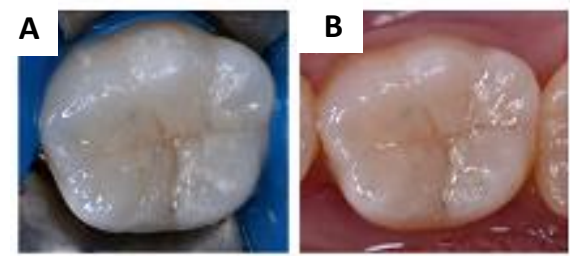

Figure 3: A) insertion of the last composite layer with grooves and pits carved out; $\mathrm{H}$ ) final appearance of the restoration after finishing and polishing.

For surface analysis by atomic force microscopy before and after polishing, specimens were prepared by inserting composite resin increments into a cylindrical metal matrix $(5 \mathrm{~mm}$ in diameter $x 2 \mathrm{~mm}$ thickness), followed by the photoactivation of each increment for 20 seconds. The specimens were analyzed with an atomic force microscope, Nanoscope IIIa (Laboratório Nacional de Luz Síncontron, Brazil) ${ }^{13}$. The atomic force microscopy images of the resin used obtained before and after polishing emphasize the necessity and clinical importance of this operative step, clearly showing the reduction of surface roughness after polishing (Figure 4) ${ }^{13}$.
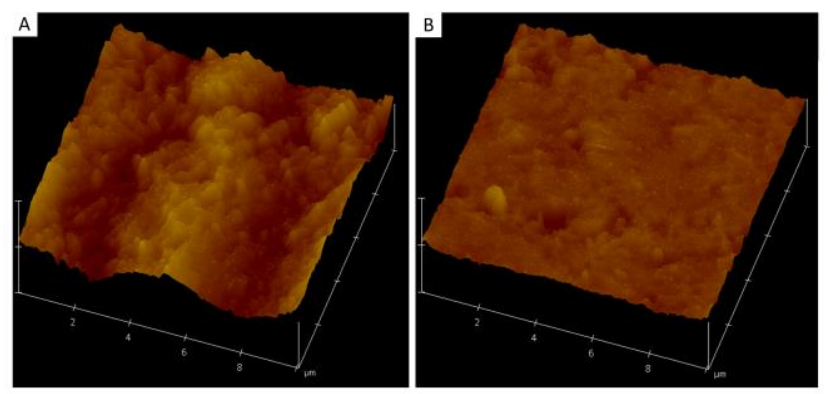

Figure 4: Atomic force microscopy images of the resin used A) before and B) after finishing and polishing.

\section{DISCUSSION}

The value attributed to the posterior teeth for smile aesthetics is a reality in dental clinical practice. The search for "invisible" restorations is a constant in dental practice and has driven the important evolution of aesthetic restorative materials ${ }^{1}$. Among the most indicated materials, composite resins and dental ceramics occupy a prominent place, each with its indications, contraindications, advantages and disadvantages $^{2}$.

Composite resins are indicated for small and medium cavities. Since they do not require the 
laboratory phase, they can be applied in a single session, permitting the execution of treatment at a more affordable cost. However, their success and clinical longevity depend on the skill, knowledge of the restorative material and technical expertise of the professional, in order to avoid possible problems such as contraction of composite polymerization, marginal infiltration and inadequate surface polishing ${ }^{2,5}$.

Several methods and polishing techniques for composites are described in the literature ${ }^{11,14}$. Surface polishing should be done one week after the restoration is completed, and can be done with rubber tips, abrasive discs, a silicon carbide brush and polishing paste, in order to obtain clinical longevity and greater surface smoothness, and to avoid future pigmentation ${ }^{14,15}$. Surface analyses by atomic force microscopy emphasize the importance of this clinical $\operatorname{step}^{12}$.

\section{CONCLUSION}

The use of composite resin by the direct technique in posterior teeth is extremely feasible as long as there is correct indication and planning, in order to associate the aesthetic excellence of this material with restorative durability and integrity. Images of atomic force microscopy emphasize the importance of polishing after completion of direct restorations with composite resin.

\section{REFERENCES}

1. Frese C, Staehle HJ, Wolff D. The assessment of dentofacial esthetics in restorative dentistry: a review of the literature. J Am Dent Assoc. 2012; 143(5):461-66.

2. Moraschini V, Fai CK, Alto RM, dos Santos GO. Amalgam and resin composite longevity of posterior restorations: A systematic review and meta-analysis. J Dent. 2015;43(9):1043-50.

3. Kovarik RE. Restoration of posterior teeth in clinical practice: evidence base for choosing amalgam versus composite. Dent Clin North Am. 2009;53(1):71-6.

4. Kanzow P, Wiegand A, Schwendicke F. Costeffectiveness of repairing versus replacing composite or amalgam restorations. J Dent. 2016; 54:41-7.

5. Lynch CD, Opdam NJ, Hickel R, Brunton PA, Gurgan S, Kakaboura A, et al. Guidance on posterior resin composites: Academy of Operative Dentistry - European Section. J Dent. 2014; 42(4):377-83.

6. Fernández E, Martín J, Vildósola P, Oliveira Junior OB, Gordan V, Mjor I et al. Can repair increase the longevity of composite resins? Results of a 10-year clinical trial. J Dent. 2015;43(2):279-86.
7. Sabbagh J, McConnell RJ, McConnell MC. Posterior composites: Update on cavities and filling techniques. J Dent. 2017; 57:86-90.

8. Constantinescu DM, Apostol DA, Picu CR, Krawczyk K, Sieberer M. Mechanical properties of epoxy nanocomposites reinforced with functionalized silica nanoparticles. Proc Struct Integ. 2017;5:647-52.

9. Yadav RD, Raisingani D, Jindal D, Mathur R. A comparative analysis of different finishing and polishing devices on nanofilled, microfilled, and hybrid composite: a scanning electron microscopy and profilometric study. Int J Clin Pediatr Dent. 2016;9(3):201-8.

10.Fernandes ACBCJ, Assunção IV, Borges BCD, Costa GFA. Impact of additional polishing on the roughness and surface morphology of dental composite resins. Rev Port Estomatol Med Dent Cirur Maxilofac. 2016; 57(2):74-81.

11. Antonson SA, Yazici AR, Kilinc E, Antonson DE, Hardigan PC. Comparison of different finishing/polishing systems on surface roughness and gloss of resin composites. J Dent. 2011; 39(Suppl 1):e9-17.

12. Kumari CM, Bhat KM, Bansal R. Evaluation of surface roughness of different restorative composites after polishing using atomic force microscopy. J Conserv Dent. 2016; 19(1):56-62.

13.Pimentel PEZ, Goyatá FR, Cunha LG. Influência da técnica de polimento na lisura superficial de resinas compostas. Clin int $\mathrm{j}$ braz dent. 2012;8(2):226-34.

14. Chour RG, Moda A, Arora A, Arafath MY, Shetty VK, Rishal Y. Comparative evaluation of effect of different polishing systems on surface roughness of composite resin: An in vitro study. J Int Soc Prev Community Dent. 2016; 6(Suppl 2):166-70.

15.Lins FC, Ferreira RC, Silveira RR, Pereira CN, Moreira AN, Magalhaes CS. Surface roughness, microhardness, and microleakage of a siloranebased composite resin after immediate or delayed finishing/polishing. Int J Dent. 2016; 2016:8346782.

\section{CONFLICTS OF INTERESTS}

The authors declare no conflicts of interests.

\section{CORRESPONDING AUTHOR}

\section{Amália Moreno}

amalia_moreno@yahoo.com.br 